\title{
205: Land Use Impacts On Water Resources - Science, Social and Political Factors
}

\author{
TIM FORSYTH
}

-Development Studies Institute, London School of Economics and Political Science, London, UK

\begin{abstract}
Public perceptions of land-use impacts on water resources are important because they influence formal environmental policies and popular attitudes about land use. For example, upland agriculture and deforestation are commonly blamed for reducing rainfall levels and for causing lowland water shortages, and some governments have consequently passed logging bans or restrictions on upland agriculture. However, there is intense controversy concerning whether these public perceptions are supported by scientific evidence; whether these policies may actually address underlying problems; and how far hydrological science is itself influenced by social and political factors. This article draws upon debates in social science (rather than hydrological science alone) to discuss linkages between public perceptions and scientific explanations of hydrological change. As examples, the article discusses the cases of so-called Himalayan environmental degradation; dryland desiccation in the Sahel; and debates concerning the impacts of deforestation and reforestation in watersheds. The article argues that hydrologists should not categorize public perceptions and formal science separately, but see both as mutually evolving. Dominant perceptions, or "narratives", of hydrological change may occur from various coincidences of historical research and public concern, and reflect the viewpoints and experiences of only selected social groups. It is suggested that hydrologists can help overcome apparent conflicts between public perceptions and scientific explanations by increasing public participation in describing and framing complex environmental problems, and using this information to make existing narratives more diverse and flexible. There is also a need to understand the political and institutional factors that lead to the persistence of contested narratives within different national or organizational contexts.
\end{abstract}

\section{INTRODUCTION}

Human• impacts on hydrological systems are a growing source of public concern. Few days seem to pass without some kind of public debate about society's impacts on water resources, which are usually seen as negative. In 2000, for example, Britain's Prince Charles once blamed a period of unusually high rainfall in Britain on "Mankind's arrogant disregard of the delicate balance of nature" ("Storms are Man's fault, says Prince" by Charles Clover, The Daily Telegraph, 7 November 2000, pp. 1). In other countries, many activists warn that excessive agriculture or deforestation will lead to desertification. Around the world, various policies and land-management schemes restrict human activities because of their presumed impacts on water resources.
But are these statements and policies justified? Can we really blame human activities for apparent problems such as water shortages or changes in rainfall? New research is suggesting that human impacts on water resources are highly varied, and that many common perceptions, or generalizations, about human impacts of land use are simplistic. These findings are fueling a debate about the origin of public perceptions of human impacts on water resources. The debate includes asking "how and why do public perceptions become seen as 'fact'?" Or, "how can we make public perceptions more accurate?"

This article of the Encyclopedia may be slightly different to others because it summarizes social and political debates rather than hydrological science alone. The article adopts a "science-studies" approach, or a focus on the political and social contexts that shape hydrological science. This

Encyclopedia of Hydrological Sciences. Edited by M. Anderson.

(c) 2005 John Wiley \& Sons, Ltd. 
approach does not suggest that hydrological science cannot help explain environmental change, but instead shows how current and historic social concerns have influenced explanations of complex environmental problems. Understanding these social influences can help make hydrological science more effective and reduce apparent conflicts between public perceptions and science.

\section{THE SOCIAL SCIENCE DEBATE ABOUT ENVIRONMENTAL "MYTHS" AND PERCEPTIONS}

What are "perceptions", and why are they important? At the most basic level, all humans have their own perceptions - or experiences of - environmental events or changes. In this sense, a "perception" may be one person's individual experience of, say, a flood, or knowledge of how hydrological events occur, or what may cause them.

But "perceptions" may also include the tendency for large numbers of people to make assumptions about the nature or causes of environmental problems or hydrological events. In this sense, perceptions are no longer controlled by individuals' experiences, but are influenced by wide-scale discourses, or "received wisdom", and which are commonly reported in books, popular discussions, and media as though they are unquestioned "facts". Some examples of common perceptions concerning hydrology include:

- Forests increase rainfall (and hence deforestation decreases rainfall).

- Agriculture in upland areas reduces the downstream supply of water from those areas.

- Agriculture in dry lands leads to desiccation and irreversible degradation of land.

- Forests in upland areas reduce erosion and prevent lowland flooding (and hence deforestation may cause erosion and flooding).

Such views are frequently adopted as "factual" by many formal organizations such as state forestry departments or international development agencies. Yet, an increasing number of researchers are now questioning these statements because they are challenged by a variety of research and other evidence (e.g. Calder, 1999; Bruijnzeel et al., 2004).

This kind of conflict between public perception and scientific research is, of course, not new, nor restricted to hydrology. Some authors have discussed the mismatches between orthodox perceptions of environmental problems and scientific research for years, and have called perceptions "myths" (see Leach and Mearns, 1996; Forsyth, 2003 for summaries). Some physical scientists have used the word "myths" to indicate scientific falsehoods, or the persistence of ideas after research should have falsified them. For example, Thomas and Middleton (1994) called desertification a "myth" because they claim recent research has made the traditional meanings attributed to "desertification" inapplicable to newer understandings of desiccation and drought (see the discussion of dryland desiccation below).

However, many social scientists have suggested that environmental "myths" should not be seen as falsehoods, but as "truths" that uphold some essence of cultural belief or knowledge (similar to ancient myths or folklore). This definition of "myth" throws the debate on its head: rather than asking why apparently false explanations still persist, we should ask why these explanations are still seen as "true" in certain contexts.

So, where do "myths" come from? For many analysts, the existence of environmental "myths" is explained by insufficient research or poor communication between scientists and the public and policymakers. Environmental problems are usually highly complex, and information is difficult to achieve for long time or space scales. Furthermore, it is not surprising that government agencies or the public cannot keep abreast of all research.

Researchers in science studies, however, consider these explanations insufficient. Instead of seeing a linear relationship - of science feeding public perceptions or policy analysts seek each as coevolving and mutually enforcing. Under science studies, researchers look more at the social and political factors that lead to the identification and research of distinct environmental problems in the first place, and then at the social barriers to communication between different disciplines, social groups, or organizations. They argue that all scientific research reflects different social framings in what is researched, and how, and how policy circles see different knowledge claims as authoritative or legitimate. This approach does not ask "why doesn't the public or policymakers listen to science?" but, "what social factors lead to different scientific explanations being considered meaningful and true?"

It is worth reviewing the two main approaches to explaining environmental myths within science studies. The earliest approach (Cultural Theory is an approach influenced by British sociologist, Mary Douglas. It distinguishes itself from other cultural studies by using a capital $\mathrm{C}$ and $\mathrm{T}$ ) argued that all societies inevitably contain four distinct social groups with specific worldviews (Schwarz and Thompson, 1990). Individualists are those seeking to maximize personal gain, and who see little social responsibilities for their actions (e.g. transnational corporations). Egalitarians are those most worried about the communal implications of social actions (e.g. nongovernmental organizations). Hierarchists are those seeking to impose rules on society in order to manage social actions and accommodate all perspectives (e.g. governments). And, fatalists are those who feel powerless to affect any change on how society works (e.g. poor farmers). According to Cultural Theory, each group will explain environmental change in characteristically optimistic, pessimistic, managerial, or fatalist 
ways. Consequently, effective environmental governance would not rely upon deciding which of these worldviews was correct, but in devising a system of government that acknowledged all environmental claims were filtered in these ways. As Thompson et al. (1986) claimed, governors should not ask the public "what are the facts?" but "what would you like the facts to be?"

Later analysts, however, have questioned whether these four groups are too reductionist. The narrative, or storylines, approach focuses instead on the historical evolution of environmental explanations as linguistically and culturally embedded conventions (see Hajer, 1995). Under this approach, environmental myths emerge historically as the result of how different social groups and conflicts have defined them. Over time, narratives are seen to be factual or universal, but reflect only a limited knowledge of biophysical events, and limited perspectives on how such processes can be perceived by different groups. Two processes are especially influential on narratives. First, narratives usually reflect a selective "problem closure", or framing of how hydrological events are seen to be problematic to selected groups of people. For example, in Bengal, India during the nineteenth century, formal forest policies prioritized teak and sal production, and the practices of shifting cultivators were seen to be inimical to the objectives of the foresters. Hill forest areas were identified as less valuable for timber production and therefore, were burnt to encourage the cultivation of less valuable products such as sabai grass (Sivaramakrishnan, 2000). A second process is the formation of "discourse coalitions", or where political negotiations between different actors may serve to reinforce a narrative. For example, historians of environmentalism in North America have claimed that industrialization was associated with a growing perception of "wilderness" as threatened, and the urgent need to protect areas such as watersheds. This may lead to a discourse coalition when conservationist NGOs and governments may disagree about levels of logging versus conservation, but agree on narratives concerning the impacts of upland agriculture on watersheds even if these impacts are uncertain. This was perhaps illustrated when the Indonesian Forum for the Environment (Walhi) brought an action against the Indonesian government in 2004 for allegedly being responsible for flash flooding in Sumatra in 2003 by allowing logging to take place in upland watersheds.

Narratives, or storylines, therefore reflect the political debates of their day, and are partly controlled by the degree of public participation in formulating them. These, in turn, have political impacts and purposes. Hajer (1995, pp. 64-65) wrote, "Storylines are devices through which actors are positioned, and through which specific ideas of 'blame' and 'responsibility' and 'urgency' and 'responsible behavior' are attributed". Other authors have suggested that narratives allow actors such as governments or development agencies to foreclose scientific debate in order to support specific policies. "Development narratives tell scenarios not so much about what should happen as about what will happen according to their tellers - if the events or positions are carried out as described" (Roe, 1991, p. 288). Accordingly, it is important not to take a narrative at face value, and to ask, instead, on whose information and framings they are based.

The following examples illustrate some well-known narratives concerning land-use impacts on water resources. This article cannot hope to summarize all aspects of hydrological research on these important topics (see Bonell and Bruijnzeel, 2004; Bruijnzeel, 2004; Chomitz and Kumari, 1998), but the purpose here is to show the links between public perceptions and hydrological science, and how changing the framings and public participation has affected explanations.

\section{HIMALAYAN ENVIRONMENTAL DEGRADATION THEORY}

One of the most famous debates relating to public perceptions of land-use impacts on water resources is the so-called "Himalayan theory of environmental degradation". This narrative was used to describe processes of land degradation in the wet Middle Hills of Nepal resulting from the effects of rapid population growth and modernization. Eckholm (1976, p. 77) summarized the "theory" when he wrote:

"Population growth in the context of a traditional agrarian technology is forcing farmers onto even steeper slopes, slopes unfit for sustained farming even with the astonishingly elaborate terracing practiced there. Meanwhile, villagers must roam further and further from their houses to gather fodder and firewood, thus surrounding villages with a widening circle of denuded hillsides."

In turn, these hillside processes have also been linked to a further vicious circle of deforestation and soil erosion that, in turn, enhance lowland floods and water shortages and sedimentation as far east as Bangladesh. Much of this narrative has been based upon the idea that forests form a "sponge" to hold water in the Middle Hills, and release this slowly throughout the year. This narrative has influenced environmental policy in various countries, and formed part of general watershed policies that link upland agriculture to lowland impacts (also see the discussion of watersheds). Indeed, the ecologist Norman Myers (1986, p. 2) wrote:

\footnotetext{
"The Himalayan forests normally exert a sponge effect, soaking up abundant rainfall and storing it before releasing it in regular amounts over an extended period. When the forest is cleared, rivers turn muddy and swollen during the wet season, before shrinking during drier periods... Flood disasters are becoming more frequent and more severe."
}

Much research, however, has questioned many of the assumptions in the Himalayan theory (see Thompson et al., 
1986; Ives and Messerli, 1989; Ives, 2004). First, not all empirical work supported the basic premises that erosion and deforestation were occurring at unprecedented rates. One survey revealed that the estimations of deforestation rates in Nepal between 1965 and 1981 varied by a factor of 67, even after excluding some apparent typing errors (Donovan, 1981). This variety indicates that biophysical processes are more complex than commonly claimed. Moreover, it suggested that different actors and organizations represented environmental change in terms to suit their own perceptions and objectives.

Second, various research has questioned whether the metaphor of the forest as "sponge" is accurate, as trees form important sources of water demand. Some authors have suggested the metaphor of "pump" is better (Hamilton and Pearce, 1988; Bruijnzeel, 2004). In order to save space, the discussion of the impacts of upland land-use change on water supplies is discussed in the later section concerning deforestation and reforestation.

Third, research from anthropologists and cultural ecologists suggested that biophysical processes were not always experienced as problematic by farmers, who either knew how to lessen them, or who developed mechanisms to protect themselves against them. For example, one study found that some farmers triggered landslides themselves in order to revitalize soil fertility and facilitate the construction of terraces (Kienholz et al., 1984). The assumption that population growth encouraged cultivation of steep slopes was also challenged by research in Nepal and Thailand, which indicated that upland farmers actually avoided steeper slopes because they knew this would accelerate erosion (Thapa and Weber, 1995; Forsyth, 1996). Studies like these showed the diversity of framings of environmental problems (or "problem closures"), and the need to consider both local evaluations of, and reactions to, biophysical changes.

And fourthly, geomorphologists argued that many processes of so-called degradation were probably more influenced by long-term geological or climatic factors that predated agriculture. For example, much mass wasting on steep Himalayan slopes can be attributed to tectonic uplift. Many deep gullies - or so-called pahiros - incising Himalayan slopes, reflect long-term erosion. Agricultural practices will inevitably have some impact on these processes, but it is unclear how far agriculture in itself is the sole cause of erosion (see also Gilmour et al., 1987).

Of course, none of these criticisms suggest that there are no environmental problems in the Himalayas, or that upland agriculture and population pressure will have no impacts. But increasingly, analysts are arguing that we need to understand the social and political factors that led to the idea of "one" single model of environmental degradation, and how this reflected western concerns about the ecological crisis during the 1960s and 1970s, rather than acknowledging the diversity of local perceptions and the complexity of biophysical processes (Gyawali, 2000; Ives, 2004).

\section{DRYLANDS AND WATER SCARCITY: DESICCATION IN THE SAHEL}

Desiccation in the context of land use refers to the drying out of land, including the possible reduction in rainfall, resulting from human actions (see Saberwal, 1997). It is usually related to the similar concept of desertification, which is land degradation in drylands. Public perceptions of desiccation and desertification usually include images of fragile land being rapidly degraded by cultivation, grazing, and urbanization. The cofounder of the Worldwatch Institute, and well-known environmentalist, Brown (2001, p. 8) wrote:

"Easily a third of the world's cropland is losing topsoil at a rate that is undermining its long-term productivity. Fully 50\% of the world's rangeland is overgrazed and deteriorating into desert."

Public perceptions of human despoliation of dryland ecosystems are not new. Scholars in the eighteenth century, for example, considered the Sahara desert to have been created by the Romans and Phoenicians as the result of deforestation, overgrazing, and overcultivation (Goudie, 2000). Such beliefs were strengthened by the apparent collapse of local empires in North Africa. In 1324, it was reported that the Emperor of Mali, Mansu Musa crossed the Sahara to Mecca with 500 slaves and 100 camels laden with gold (Bass, 1990, p. 13). The caravan's arrival en route in Egypt depreciated the precious metals market there by $12 \%$, and spread rumors of the fabulous wealth of the empire's capital in Timbuktu. The empire declined, however, as the result of competition from new Portuguese and Spanish empires, and in 1738 half the population of Timbuktu died of famine. When the city was visited in 1828 by a French traveler, he wrote graphically of his shock at finding apparent evidence of human failure in a barren land:

"I looked around and found that the sight before me did not
answer my expectations... [The city] presented, at first view,
nothing but a mass of ill-looking houses, built of earth. Nothing
was to be seen in all directions but immense plains of quicksand
of a yellowish-white color. The sky was a pale red as far as the
horizon, all nature wore a dreary aspect; and the most profound
silence prevailed; not even the warbling of a bird was to be
heard" ( $\bullet$ René Caillié, 1828 , in Bass, 1990, p. 13$)$. $Q^{2}$

In time, such views led to the narrative that local land uses, and particularly agricultural intensification and grazing, were responsible for desertification. This was especially true in the Sahel, or the strip of land immediately south of the Sahara, and comprising some of Africa's poorest countries such as Chad and Burkina Faso, and which has 
experienced sever drought since the 1970s. One British colonial administrator wrote about East Africa in 1937:

"Anyone possessing some knowledge of the desert-country
types can come and study the stages, quite sufficiently clear-cut
once the eye is attuned to discerning them, by which the desert
has through the centuries, assisted by man (sic), advanced over
rich and fertile regions" (Stebbing, 1937, p. 1).

And consequently, many land-management policies have sought to control the physical processes of desiccation such as by using fences to restrict sand movement - or restrict activities such as grazing. But again, the narrative linking desiccation to land use alone has been questioned. As with Himalayan degradation, criticisms have highlighted the role of human impacts vis-à-vis preexisting long-term biophysical processes. At the most fundamental level, land uses have not caused the existence of deserts, but these have developed because of long-term climate patterns influenced by large volumes of rising hot air (Goudie, 2000). Other studies have pointed out that many dryland zones - such as the Namib Desert of southwest Africa - are subject to cycles of relative wet and dry periods of precipitation, and consequently these cycles need to be considered before any analysis of land-use impacts (Thomas and Middleton, 1994). Other biophysical changes are difficult to estimate. Some analysts have sought to model impacts of land use-cover change on desiccation (for example, see Sud and Fennessy, 1982; Nicholson, 1988; Xue, 1997). But these models may be questioned too. For example, it may be reasonable to propose - as some of these models do - that rainfall may decrease by $25 \%$ if (say) an acacia savanna ecosystem was replaced by grassland used for pastoralism. But there are (at present) insufficient measurements, for the critical times, to indicate whether such changes took place. Plus, such changes are reversible, and are constantly in flux (Hulme, 2001, p. 26).

Critics have also questioned the public perception of drought itself. Hulme (2001) argues that the primary problem concerning public perceptions about the Sahel is the belief in the concept of a uniform climate that is in equilibrium. Instead, the climate - and associated drought is highly variable over space and time. This implies that different localities have diverse experiences of climatic change. Furthermore, the concept that there is necessarily a problem of drought in the Sahel implies that the region has departed from some "normal" level of precipitation that is clearly identifiable. The so-called Sahel drought became a topic of international concern in 1972 and 1973, which were the region's driest years on record. At this time, analysts tried to predict the length of the drought according to past periods of dryness. But, counter to expectations, the years 1983 to 1985 were then even drier. The long-term trend suggested further desiccation. For the period 1931 to 1960 , the 30-year average Sahel rainfall was $520 \mathrm{~mm}$. Between 1941 and 1970, it was $512 \mathrm{~mm}$. 1951 to 1980 was measured at $488 \mathrm{~mm}$ and 1961 to 1990 was measured at $428 \mathrm{~mm}$. The predicted level for 1970 to 2000 was $410 \mathrm{~mm}$ (Hulme, 2001 p. 24). On this basis, perhaps it is more important to see the current "drought" as normal, and instead seek to explain how the decades of the 1920s, 1930s, and 1950s were comparatively wet.

The implications of these concerns is to place less emphasis on "desertification" or "desiccation" as identifiable processes with known causes and effects, and instead to see each as more varied and governable in different ways. For example, recent research has suggested that increasing land use, combined with dust storms, may be responsible for maintaining high levels of atmospheric dust over the Sahel, which may be responsible for reducing rainfall. Indeed, the growth in off-road vehicles may disrupt surface crusts and lichens and hence release dust to the air (Goudie, 2004). Similarly, social science researchers have urged more attention to the socioeconomic causes of vulnerability to drought within Sahel communities (Batterbury and Warren, 2001). For example, it may be more effective to encourage local technologies of rainwater harvesting as a response to drought, rather than to address only the broad causes of drought. In both these physical and socioeconomic cases, the approaches allow more flexibility in explaining environmental problems in the Sahel, and allow research to identify both the causes and responses to desiccation in more locally grounded ways. This does not mean suggesting drought or desiccation do not occur, or that they are not problematic. But it means we should replace simple narratives focusing on single causes with those that incorporate greater awareness of the narrative's history, and more local participation about current experiences and exposures to risk.

\section{DEFORESTATION AND REFORESTATION IN WATERSHED ZONES}

The examples of Himalayan degradation and desiccation in the Sahel are examples of narratives linked to specific locations. But the impacts of deforestation and reforestation in watershed areas are equally controversial and more general. Public perceptions in various countries attribute various land-use impacts on water resources, notably that deforestation will decrease levels of rainfall, or that upland agriculture will cause lowland water shortages, especially during dry seasons. In turn, it is commonly believed that reforestation is an adequate solution to these problems.

Yet, these views are also questioned. Sometimes, critics include those who oppose forest protection in order to allow logging. But other critics instead ask whether these explanations of hydrological impacts are simplistic, and whether the proposed solutions will be effective, or whether they would unnecessarily interfere in farmers' livelihoods. Again, this article cannot hope to discuss all aspects of 
these hydrological debates (see Bruijnzeel, 2004), but seeks to illustrate the coevolution of perceptions and scientific narratives. Four themes are discussed: the meanings and extent of deforestation and the impacts of deforestation or upland agriculture on rainfall, lowland water flows, and erosion.

\section{Defining “Deforestation"}

For many analysts, "deforestation" is a narrative in itself (Fairhead and Leach, 1998). Public perceptions usually state that deforestation is universally damaging, even though the term comprises great diversity. The impacts of deforestation on hydrological resources depend on its extent, and on the local socioeconomic needs attributed to those resources.

First, public perceptions often consider deforestation a wide-scale and uniform phenomenon. Undoubtedly, in many locations, deforestation has occurred at alarming rates, and continues to do so. But our knowledge of deforestation rates is highly varied. Comparisons of satellite data and ground surveys of forests, for example, suggest that some estimates based upon satellite imagery alone exaggerate rates of forest loss because of the simplifications and assumptions used in making estimates at different spatial scales. For example, Fairhead and Leach (1998, p. 183) estimated that total forest loss in six West African countries since 1900 may reach 9.5 to 10.5 million hectares, rather than commonly discussed estimates of 25.5 to 30.2 million hectares. (Indeed, some agencies, such as the World Conservation Monitoring Center, have placed deforestation in this region even higher, at 48.6 million hectares). As with Himalayan environmental degradation, we need to acknowledge the diversity of these estimations and ask why statistical uncertainties are often not acknowledged, and, accordingly, become seen as "fact".

Moreover, there are diverse framings or classifications of "deforestation". The term often conjures images of clearfell logging, such as in the Amazon. But widespread deforestation for commercial logging should not be confused with selective logging, the harvesting of nontimber forest products, or the cyclical burning and regrowth under forms of shifting cultivation (sometimes known in more extreme forms as "slash and burn" agriculture). Under these diverse forms of forest usage, it is crucial to consider what is meant by "deforestation". Each will have different impacts on resources. As two critics wrote:

"The generic term "deforestation" is used so ambiguously that it is virtually meaningless as a description of landuse change... It is our contention that the use of the term "deforestation" must be discontinued, if scientists, forestland managers, government planners, and environmentalists are to have meaningful dialogue on the various human activities that affect forests and the biophysical consequences of those actions" (Hamilton and Pearce, 1988, p. 75).
Similarly, there are various meanings of the word "reforestation". Afforestation is commonly meant to imply planting trees where there were previously no forests, whereas "reforestation" is planting trees in sites of previous forest. Yet, of course, it is important to distinguish between monoculture forest plantations, and carefully reseeded, long-term reconstructions of diverse ecosystems. Some outspoken public perceptions are strongly for or against plantations, either because they are seen to be effective ways of replacing forests (including for the purpose of carbon sequestration) or because they are seen to be ineffective for hydrological or biodiversity problems, and may also exclude local land users from agricultural land. Eucalyptus plantations have especially been criticized because they have been associated with commercial forestry with little impacts on local economic growth, yet their fast growth rates usually absorb much water from local fields. A full investigation into the nature and impacts of reforestation/deforestation is beyond this article, but it is important to note that these terms evoke important, and historical, meanings, and are highly varied.

\section{Do Forests Increase Rainfall?}

Many public perceptions assume that deforestation reduces rainfall. For example, a magazine for tourists in Thailand carried an article entitled "There's no doubt - it's a drought!" by Thammasak Thinnsawat and David Hardy, Good Morning Chiang Mai, vol. 4 no. 3, pp. 12-23. March 1999 which claimed: "the bottom line is forests decimated by excessive tree felling and land denuded by slash and burn agriculture severely reduce cloud formations - and thus rainfall, the main cause of Thailand's drought". Similarly, the leader of the Chipko environmental movement in India once claimed that cutting forest results in drought (World Water, 1981). The link between forests and rainfall is easy to make, because so many forests exist in rainy areas - notably rainforests and mountainous zones.

Research, however, has sought to redefine these narratives. At one level, the presence of forests will usually influence cloud formation because of higher levels of evapotranspiration and humidity than experienced under other land uses. But much research has suggested, instead, that many forest areas follow, rather than cause rainfall, and that long-term patterns of climate and topography have more influence on precipitation than forests. Moreover, the impacts of deforestation on albedo (or atmospheric reflectivity) are also considered less dramatic than originally thought because most replacement vegetation has similar reflective values.

Research into the impacts of deforestation on rainfall is usually hard to achieve because a temporally monitored experiment, using a large land area, is infeasible. Furthermore, these studies do not always use the same baseline or extent of "deforestation", or acknowledge the impacts 
of other climatological factors such as the El Nino Southern Oscillation. But various studies using time-series data or simulations have suggested that there is little statistical evidence for forests causing rainfall. There are many examples. One of the earliest studies (Bernard, 1953) found no evidence for forests influencing rainfall in the Central Congo Basin (estimated one million $\mathrm{km}^{2}$ ). Research in Russia, reviewed by Shpak (1968) indicated that forestland produces approximately $10 \%$ more rainfall than land without forest (in Hamilton, 1988, p. 103). In southern India, annual rainfall over the last 100 years has not decreased, even despite the general conversion of the dry deciduous forest to agriculture, although evidence suggests a decline in the number of rainy days (Meher-Homji, 1980). Tangtham and Sutthipibul (1989) found a negative correlation between 10-year moving averages of annual rainfall and remaining forest area in northern Thailand, 1951 to 1984, but a positive correlation between forest area and number of rainy days. A further study found no changes in rainfall totals or patterns on the $12100 \mathrm{~km}^{2}$ Nam Pong basin in northeastern Thailand between 1957 and 1995, despite a decrease in areas classified as forest from $80 \%$ to $27 \%$ since the 1970 s (Wilk et al., 2001). And in the Amazon basin, Global Circulation Models have suggested that removing even the entire Amazon basin would result in reduced rainfall, especially in the dry northeast of Brazil, of only an average of about $0.5 \mathrm{~mm}$ per day (Rowntree, 1988).

But, of course, these studies do not suggest that forests have no influence on rainfall. Some simulation studies suggest forest conversion over areas between 1000 and $10000 \mathrm{~km}^{2}$ may cause delays in the formation of clouds. This result was found, for example, in deforested areas of southwestern Amazonia (Cutrim et al., 1995). Similarly, reductions in clouds was observed over deforested parts of Costa Rica during the dry season, but these reductions were not observed in neighboring Nicaragua in regions with good forest cover (Lawton et al., 2001). Most importantly, there is strong evidence that some forests do influence rainfall in specific locations such as coastal or montane regions, where fog may coincide with tall vegetation. In such "cloud forests", cloud-water interception may account for some $5 \%$ to $20 \%$ of ordinary rainfall, and even more in exposed sites (Bruijnzeel, 2004, p. 9). In these locations, deforestation is likely to have notable impacts on local levels of precipitation and lowland supply of water.

The public perception that forests cause rainfall reflect a general trend to see deforestation as damaging to water resources, and is supplemented by popular beliefs about water supply and erosion.

\section{Do Forests Increase Runoff?}

A further public perception is that deforestation - and associated activities such as upland agriculture - may disrupt water supplies to the lowlands, notably by reducing supplies during dry seasons or by increasing flooding during peak flows. Linked to this, some organizations have called for reforestation in upland areas to prevent water shortages. Countries such as Thailand and China have also implemented logging bans partly for these reasons. One of the common beliefs underpinning these interpretations is that forests act as a "sponge" in watersheds, which hold water throughout the year. Converting the forests to agriculture may result in losing this sponge effect, and hence damage the water-holding properties of watersheds.

A variety of public experiences have confirmed or contradicted these statements. There are numerous reports within lowland sites of springs drying up after deforestation. But there are similar reports following reforestation. Some researchers have consequently argued that we need to distinguish more closely between total water yields, and the seasonal distribution of flows (Bruijnzeel, 1990). Similarly, it is difficult to generalize about land-use impacts on the basis of information from various sites, which vary in terms of underlying geology and climate, and, again, in terms of how deforestation is defined and experienced.

That said, many hydrologists agree that removing forest cover by a third or more results in significant increases in streamflow because of reductions in evapotranspiration. In effect, this is to suggest that forests do not necessarily act as "sponges" in watersheds, but as "pumps". As Bruijnzeel (1990, p. 84) wrote:

"Removal of forest cover leads to higher streamflow totals and reforestation of open lands generally leads to a decline in overall streamflow."

And similarly, various studies suggest that upland agriculture, or limited forms of deforestation, may impact only marginally on lowland water supplies. Alford (1992) in Thailand, for example, concluded that there was no apparent connection between net runoff from river basins and shifting cultivation between 1976 and 1987 (although it is worth noting that much deforestation from shifting cultivation started in the nineteenth century, and so these results may not be fully representative). In Africa, two studies estimated the increase in water supply following the conversion of forests to crops was an estimated $140 \mathrm{~mm}$ per year in Nigeria (Lal, 1983) and $410 \mathrm{~mm}$ per year in Tanzania (Edwards, 1979). No declines in annual streamflow have been reported following lowland tropical forest removal (Bruijnzeel, 2004, p. 15). Such results have also been applied in reverse in relation to the impacts of reforestation. For example, Bosch (1979) found that afforestation of former grasslands with pine resulted in reductions in both annual streamflow (of $440 \mathrm{~mm}$ ) and during the dry season (of $15 \mathrm{~mm}$ ). These were supported by later research in South Africa by Scott and Smith (1997) who also found that the reduction in dry season flows were actually greater than the reduction in annual flow rates. In Kenya, water yields have 
been reported to return to original levels within eight years

Q3 where pine plantations replaced forests (•Blackie, 1979). Bruijnzeel (2004, p. 24) wrote:

"The conclusion that already diminished dry seas flows in
degraded tropical areas may decrease even further upon refor-
estation with fast-growing tree species seems inescapable."

Yet, these findings are contingent upon a variety of local contexts, and particularly the protection of soils under and around forests. The case of tropical montane cloud forests generally experience low evapotranspiration, and removing these forests may also reduce the impacts of this vegetation on channeling water to the ground (see discussion of rainfall and deforestation). Different geological zones have varying runoff efficiencies (or the ratio between water input as precipitation and output as streamflow). Alford (1992), for example, estimated basins in Thailand to have a comparatively low efficiency of just $20 \%$. This low efficiency, and the observed lack of responsiveness from rainfalls to lowland flows were attributed to the extraction of water by local irrigation and dams before they reached the main river channels (Walker, 2003). Different soil conservation measures may also enhance or reduce the ability for soils to hold water. (The topic of erosion is discussed in the Section "Do forests reduce erosion?").

Similarly, the influence of land-use changes on flooding is also controlled by local topographical and climatic factors such as rainfall events, hydraulic conductivity of soil, and slope morphology. It is therefore difficult to find clear relationships between simple criteria and flooding. In Nepal, for example, Hofer (1993) found no statistically significant relationships between river discharge, precipitation, and flooding in large watersheds between Nepal and the Gangetic plain. After analyzing some 40 years of data, he later wrote of the Ganga-Brahmaputra-Megha river system:

"It can be inferred that floods are a normal process in the Ganga-Brahmaputra-Megha lowlands. Neither the frequency nor the magnitude of flooding has increased over the last few decades. Consequently there is no reason to believe that floods in the lowlands have intensified as a result of human impact in the highlands" (Hofer, 1998).

Q4 Earlier• research in the Nepal-Himalayan region produced similar results at a smaller scale. Marston et al. (1996, p. 1) studied data at 22 stream crossings together with drainage basin morphometric data and information about forest cover to identify the controls on bank-full discharge from monsoon storms. They claimed: "results demonstrate that $82 \%$ of the variation in bank-full discharge can be explained as a function of drainage area alone; forest cover did not add explanatory power" (see also Calder and Aylward, in press).

As with other biophysical events, the framing and perceived frequency of floods may reflect socioeconomic trends. The dramatic impacts associated with flooding may frequently be linked to the increased financial valuation of flood damage, and the trend towards locating housing and economic activities on floodplains, rather than a universal increase in the size and frequency of floods. Hamilton and Pearce (1988, p. 87) warned that public perceptions often misplace the causes of flooding:

\begin{abstract}
"These stormflow effects must not be extrapolated to support statements that appear in the press (and the misconception commonly held) that logging in upper watershed is the principle cause of serious and widespread flooding in the lower reaches of major river basins."
\end{abstract}

This article cannot hope to summarize the diverse and large literature concerning land-use impacts on water flows. Instead, the purpose is to illustrate the strength of public perceptions despite various hydrological studies that question them. These differences are discussed further after the final exploration of deforestation and erosion.

\section{Do Forests Reduce Erosion?}

It is generally agreed that severe soil erosion can seriously damage the ability of soils to hold water. Erosion also restricts the supply of nutrients and water to plants. Cultivation of steep slopes usually accelerates erosion, and the removal of tree canopies can accelerate splash erosion, at least in the short term. Many policy statements therefore state that upland cultivation is a primary cause of erosion, and that reforestation can help reduce erosion. Indeed, much statistical information about different rates of soil erosion show that sheet (or surface) erosion occurring under forests is much less than under agricultural plots.

Hydrological research does not question the general perception that erosion is problematic, or that agriculture can accelerate erosion. But there are various questions about how far upland agriculture is the primary cause of erosion, or how far reforestation is a solution. First, many authors have pointed out that much debate about erosion and watershed degradation overlooks the role of naturally occurring erosion, which can also occur under forests, although mainly in hilly areas. As discussed under Himalayan degradation, many deep gullies (called pahiros in Nepal) predate agriculture, and can occur in forestland. Similarly, gullies on agricultural plots in South Africa and Thailand should not be blamed on agriculture, but should instead be seen as characteristic of granite weathering (Twidale, 1982; Froehlich, and Starkel, 1993; Forsyth, 1996). A further category of erosion is mass wasting, or landslips, which have generally been linked more to climatic and geological factors (including tectonic uplift) rather than the impacts of agriculture or deforestation. Statistics that show less erosion under forests than on agricultural land are usually based on the measurement of sheet (or surface) erosion. Sheet erosion is still an 
important form of erosion and does reduce agricultural productivity and water-holding properties of soils. But full measurements of erosion should also include other forms of erosion.

Second, some studies have also suggested that reforestation using plantations can accelerate erosion. Teak (Tectona grandis), for example, has been shown to increase splash erosion because of its large-sized leaves, and hence reforesting land with teak plantations in order to reduce erosion may have surprisingly counterresults (Calder, 1999, p. 30). Trees exposed to fire may also find that litter layers burn quickly, thus exposing soil to erosion.

Thirdly, various studies show that hill farmers have acknowledged the problem of erosion and taken steps to reduce it or avoid it. This topic also implies asking how different land users frame the problem of erosion, and this has been controversial. For example, many studies of farmers' perceptions of soil erosion have produced results that erosion is not perceived to be a problem by farmers, and this has occasionally reinforced narratives that farmers do not care about the impacts of upland agriculture on environmental problems. It is indeed likely that many farmers do not perceive impacts of erosion on watershed properties, and this may be especially true for the so-called "pioneer" form of shifting cultivators who historically relocated villages every 10 to 20 years in

Q5 search of fertile ground (•Harper and El-Swaify, 1983). But various social scientists have pointed out that the word "erosion" usually means different forms of degradation to different users, and that farmers are certainly more likely to perceive problems of declining soil fertility, of which erosion is a part, rather than erosion per se. On this basis, various studies have shown how farmers may avoid overall problems of soil degradation by adopting soil conservation measures, or organizing agriculture to avoid steep slopes (for example in Amazonia: Nortcliffe and Dias, 1988; in Papua New Guinea: •Sillitoe, 1991; and in Sarawak: Hatch, 1983; •Douglas et al., 1992.)

Local• land-use patterns and vegetation may also have an impact on how far soil erosion on slopes may result in sediment yields in rivers. Alford (1992) in Thailand, for example, found that suspended sediment transport in northern Thailand is comparable to the lowest values mea9 sured in river systems of the world $\bullet$ of between $44 \mathrm{t} \mathrm{km}^{-2}$ (Ping river) in to $256 \mathrm{t} \mathrm{km}^{-2}$ (Nan river). For comparison, the more arid and tectonically active Hunza river of Pakistan has a sediment load of $13200 \mathrm{t} \mathrm{km}^{-2}$, while the Tamur river in eastern Nepal carries $5500 \mathrm{t} \mathrm{km}^{-2}$. Moreover, the relationship between streamflow and sediment transport in Thailand was observed to be more constant on a year-toyear basis than streamflow and precipitation. Alford argued that these findings suggest that the sediment in Thailand's rivers is more likely to come from sources within the stream channel rather than erosion from slopes. This again suggests that local dams and rice fields trap both water and sediment from higher slopes, and hence that eroded material may not travel very far. Indeed, these results have been found in other cultivated slopes (Trimble, 1983).

Some studies have shown increases in sediment yield when farmers have removed logs or other barriers that act as barriers for soil movement (e.g. in West Java: Bons, 1990). The construction of roads, however, has been blamed for accelerating erosion. In Indonesia, one study suggested that rural roads were just $3 \%$ of the study area, but contributed disproportionately to the total basin sediment yield (Rijsdijk and Bruijnzeel, 1991). Similar results have also been found in Africa and South America (see Ziegler and Giambelluca, 1997).

Again, of course, the purpose of this discussion is not to suggest erosion is unproblematic or that upland agriculture does not cause erosion. The purpose is to challenge simplistic narratives that blame erosion on agriculture alone, or which suggest that reforestation is an adequate response. Frequently, actions by the state such as road construction or plantation forestry may even increase erosion. Reducing erosion from agricultural land is clearly necessary, but considering different framings and the variety of hydrological research on this theme will inevitably result in more complex and more effective explanations and policy responses.

\section{Linking Public Perceptions and Science}

Of course, there is insufficient space in this article to review all debates and information about watershed degradation. But it is clear that there are many differences between common public perceptions of environmental problems in watershed areas and scientific explanations. Why do these differences exist? What do they tell us about the relationship of science and public concern?

As discussed in the section on environmental "myths", environmental narratives arise from the unquestioned adoption of existing explanations for phenomena based on historic framings of events and partial public participation in the formulation of explanations. Some watershed narratives have clearly been constructed from the viewpoints and experiences of some, rather than all, social groups. For example, the perception that upland agriculture may cause lowland water shortages may reflect the experiences of many lowlanders that water shortages are increasing, and the framing that watershed zones should be managed to increase water supplies to the lowlands. But shortages may also occur because of growing lowland demand for water, and an alternative framing of watershed areas may also acknowledge the potential impacts of reforestation and resettlement on upland livelihoods. If a narrative is a succinct summary of cause, effect, blame, and responsibility, then it is not surprising, perhaps, that some actors may seek to find solutions for problems that do not involve 
changes to their activities, but instead seek to attribute causes elsewhere.

Similarly, dominant public perceptions or narratives may also emerge because of the great uncertainty and contestation of environmental policy in many locations, and the relative absence of inclusive and critical arenas for environmental policy formulation. Universal hydrological "laws", or statements of cause and effect, are difficult to achieve because of the variety of contexts in which landuse changes occur, and the diversity with which different users evaluate or frame impacts. It is difficult to generalize conclusions between different scales because of the growth in complicating factors and concurrent changes at larger scales. Furthermore, words such as "deforestation" and "upland agriculture" are often used without acknowledging the diversity they contain. Debates may be dominated by actors who fear that "deforestation" means logging, or that "agriculture" implies the most destructive forms of slash and burn, when in fact there are various less damaging forms of cultivation in-between.

The nascent character of many environmental policymaking arenas, and a relative lack of participation in the application formal expertise, may also contribute to the evolution and persistence of narratives. In rapidly developing countries such as Thailand or Nepal, environmental politics may also be dominated by new political allegiances between the state and domestic activists (see Ives, 2004). As discussed above, classically this trend has been associated with a desire of urban middle classes to perceive "wilderness" as threatened, and hence to protect forests or watersheds from the impacts of modernization or population growth. These desires may coincide with those of the state to assert ownership over forestland, or to place controls on mountainous or watershed zones for other reasons such as national security. As discussed in the section on "myths", these alliances may "discourse coalitions" in favor of reforestation and restrictions on agriculture, despite evidence questioning the hydrological assumptions of these policies. The lack of local arenas for discursive governance (where both local experiences and framings of environmental problems can occur), or the domination of scientific discourse by state agencies, may strengthen narratives.

But it is important to note that criticizing these narratives is not the same as suggesting that there should be no concern about watersheds, or that upland agriculture has no impact. As with debates about Himalayan degradation and dryland desiccation, the objective has been to assist scientific explanation by showing the simplicity of the narratives, and identifying more relevant and locally determined targets of research. This involves diversifying public participation in research and policymaking. Bruijnzeel (2004), for example, suggests that the debate about tropical forests and hydrology risks focusing too much on questions concerning forest protection, rather than highlighting the important supplemental role of soil protection. This suggestion is clearly justified for the purposes of securing lowland water supplies because evidence suggests that soils may be more accurately described as a "sponge" than forests. But protecting soils may also address upland framings of environmental problems by protecting agricultural productivity. Reframing environmental narratives to focus on new targets may allow the creation of more holistic and equitable forms of environmental policy. Protecting upland livelihoods as well as watershed properties may also reduce the socioeconomic driving forces behind some forms of agricultural expansion and deforestation. Furthermore, policymakers should investigate other explanations for water shortages, such as the role of increased water demand in the lowlands, or introducing ways to make lowland settlements less vulnerable to events such as floods.

\section{CONCLUSION}

Public perceptions of land-use impacts on water resources are often dramatic and simplistic. But it is wrong to see perceptions as "separate" from science. Instead, both public perceptions and scientific explanations coevolve historically, and many expert bodies such as government agencies or scientific organizations share these perceptions. Consequently, it may be better to call public perceptions "narratives" because they are succinct summaries of complex events that are taken as true by various actors. Certain narratives can dominate, or be seen as unquestioned "facts", when there are sufficient supporters of the explanation, or when alternative explanations are less publicized or seen to be less applicable by the people currently involved in the policymaking process.

This article has summarized three debates where such narratives exist: "Himalayan" environmental degradation, dryland desiccation in the Sahel, and impacts of deforestation and reforestation in watersheds. In these cases, complex biophysical processes involving various elements of serious land degradation have been linked to public perceptions or narratives - of change that have been questioned by various types of hydrological research. Many physical scientists have suggested that the way to improve the accuracy of these narratives is to conduct more research, and to enhance communication between scientists, the public, and policymakers. While these actions are, of course, welcome, many social scientists suggest such strategies are insufficient because they do not acknowledge the social and political origins of narratives and their persistence. As an alternative, social scientists, and particularly science-studies scholars, argue that we should look at the mutual dependencies of science and public perceptions, and to use this knowledge to enhance hydrological research. 
The first, and most important, point made under a narrative approach is that narratives serve to foreclose scientific and political debate. Believing, for example, that upland agriculture always causes lowland water shortages (and that, consequently, upland reforestation will solve this problem) may be used to legitimize reforestation or the relocation of villages without public debate. A more critical approach would question the hydrological evidence for this presumed relationship of agriculture and water shortages, plus how far this relationship reflects framings of specific social groups (see sections above). For example, in Thailand, many government agencies, environmental activists, and media repeat the narrative that upland agriculture has to be restricted or partly replaced by upland reforestation in order to regulate dry season water flows and avoid lowland water shortages. Yet, much research suggests that reforestation (if done on a widespread level) may actually reduce flows, and that water shortages may be better addressed by managing lowland water demand. A more holistic approach might ask how far lowland water supplies, reforestation, and upland agricultural livelihoods can be enhanced concurrently. Diversifying the framing of problems - by seeing problems as both in lowland and uplands, rather than simply for the viewpoint of lowlanders - may therefore lead to more effective and more equitable solutions. Indeed, this approach may result in scientific progress by rejecting explanations that have been questioned by research, and instead refocusing research on topics that are considered more relevant. As discussed above, it may be necessary to see upland soil protection, rather than forests alone, as a means of protecting both upland livelihoods and lowland water supply.

Foreclosing of debate may also take place through the Q10 unquestioned used of language. For example, •Blaikie and Brookfield (1987, p. 4) famously remarked that "one farmer's soil erosion is another's soil fertility". Of course, this statement does not suggest that erosion (or sedimentation) is unproblematic. But it shows how words such as "erosion", "deforestation", or "wilderness" evoke images of environmental cause and effect, or of the status of a particular problem. Adopting a narrative approach requires seeing the implicit meanings in these words, and the specific histories of how these meanings were identified, and with whose participation. A narrative approach acknowledges the cultural embeddedness of supposedly "factual" words and explanations in order to show how alternative framings and experiences may lead to different explanatory conclusions. There is also a need to see much more diversity and contestation - within terms such as "deforestation" in order to indicate that this does not always imply "logging", or similarly that "upland agriculture" or "shifting cultivation" need not necessarily mean the most stereotypically destructive forms of "slash and burn".
The existence and persistence of narratives reflect the degree of public participation in formulating scientific explanations. Enhancing participation increases the range of information about biophysical events, and diversifies how events are framed. Many environmental "myths" remain unchallenged because alternative framings are not seen to be necessary, and because existing narratives do not interfere with current socioeconomic activities. For example, the old "myth" that the Sun rotates around the Earth has been challenged by science for centuries, and would make some activities - such as space travel untenable. But for the majority of humans, there is no practical need to challenge this myth, and most people still say "the Sun rises in the morning", even though this statement is clearly inaccurate. In similar ways, many narratives of watershed degradation are unchallenged by lowlanders because they have not yet considered alternative framings of watershed policies from people living in highlands. But the increasing consideration of alternative framings, and the realization that old narratives do not explain growing problems such as water shortages, may gradually lead to a reevaluation of popular explanations. Indeed, some countries such as South Africa and New Zealand have replaced the old narratives of watershed degradation within water policies, and have adopted more diverse and holistic approaches to integrated forest and water management (Calder, 1999). It is worth asking why some countries have adopted this approach when others have not.

Of course, there are some important caveats. Adopting a narrative approach does not imply replacing one simplistic narrative with another. Bruijnzeel (2004), for example, has suggested that debates about upland watershed degradation are commonly divided between narratives for or against forest protection, and consequently, criticizing orthodox watershed explanations may enhance logging. This statement is misplaced. As discussed above, a narrative approach aims to show the social or political influences on any scientific explanation, and does not seek to dismiss forest protection or any other choice as policy options. Moreover, Bruijnzeel's statement confuses normative positions and statements of causality. Forest protection can be justified normatively on various social, political, or ecological reasons. But it is becoming increasingly difficult to justify forest protection on behalf of many of the watershed narratives discussed above. As Hamilton and Pearce (1988, pp. 92-93) noted some years ago, "Banning forest product harvesting on the basis of the basis of the harmful soil and water consequences of 'deforestation' is aiming at the wrong target". Rather than clinging onto such scientific explanations as justifications for normative positions, policymakers should ask how they can still achieve forest protection in more diverse and transparent ways. 
That said, the analysis of narratives remains a politicized activity. The political implications of adopting or opposing environmental narratives need to be acknowledged. Many authors have argued that narratives persist for self-interested reasons, and some critics have suggested that criticizing narratives may also be to legitimize agendas. Roe (1991), for example, claimed narratives allow development agencies to predefine "problems" in order to demonstrate "successful" aid work. Similarly, Thomas and Middleton (1994) suggested the government of Chad used narratives of desertification during the 1980s to avoid implementing democratization. Others have suggested state forestry departments also enforce narratives as ways to maintain control over forests (e.g. Fairhead and Leach, 1998). Pereira (1989, p. 1), for example, wrote:

\begin{abstract}
"The worldwide evidence that high hills and mountains usually have more rainfall and more natural forests than do the adjacent lowlands has historically led to confusion of cause and effect. Although the physical explanations have been known for more than 50 years, the idea that forests cause or attract rainfall has persisted. The myth was created more than a century ago by foresters in defense of their trees... The myth was written into the textbooks and became an article of faith for early generations of foresters."
\end{abstract}

Allegations like these should be made with care: forest hydrologists, development agencies, and state forestry departments all do good work, and many individuals acknowledge the controversies associated with some of these narratives. Yet, there is still a need to understand how narratives may persist despite the accumulating scientific evidence against them. In turn, this requires analyzing the relationships between public perceptions and scientific advice within specific networks or institutional contexts. For example, some critics have questioned whether the "Alternatives to Slash and Burn" (ASB) initiative of the Consultative Group on International Agricultural Research (CGIAR) may - by its very name - repeat narratives and foreclose scientific debate about the impacts of this kind of agriculture (see Forsyth, 2003, p. 146). According to the ASB: "the consequences of (slash and burn) are devastating, in terms of climate change, soil erosion and degradation, watershed degradation, and loss of biodiversity" (ICRAF, 1999). As discussed above, many studies have suggested these criticisms cannot be applied to all forms of shifting cultivation. Moreover, this statement seems to frame problems of climate change and biodiversity loss within debates about agricultural smallholdings, and hence may allocate notions of "blame" and "responsibility" for these problems in ways that some critics suggest should be applied primarily to more obvious targets such as industry or cities. More research is needed on how formal expert organizations frame and help shape public perceptions of hydrological problems, and why some countries and organizations persist in using narratives and others have stopped.

\section{FURTHER READING}

-Blaikie P., Cameron J. and Seddon D. (1980) Nepal in Crisis: Growth and Stagnation at the Periphery, Oxford University Press: Oxford.

Blythe W., Dolman A. and Noilhan J. (1994) The effect of forest on mesoscale rainfall: an example from HAPEX-MOBILHY. Journal of Applied Meteorology, 33, 445-454.

Calder I. and Aylward B. (2002) Forests and Floods: Perspectives on Watershed Management and Integrated Flood Management, FAO, and Newcastle, University of Newcastle: Rome.

Dixit A. (2002) Basic Water Science, Nepal Water Conservation Foundation: Kathmandu.

Douglas I., Greer T., Bidin K. and Spilsbury M. (1993) Impacts of rainforest logging on river systems and communities in Malaysia. Global Ecology and Biogeography Letters, 3(4-6), 245-252.

Hamilton L. (1987) What are the impacts of deforestation in the Himalayas on the Ganges-Brahmaputra lowlands and delta? Relations between assumptions and facts. Mountain Research and Development, 7, 256-263.

Hewlett J. (1982) Forests and floods in the light of recent investigation. Proceedings of the Canadian Hydrological Symposium, Frederiction, June 14-15, pp. 543-560.

Ives J. (1980) Conservation and development in northern Thailand. In Proceedings of a Programmatic Workshop in Agroforestry and Highland-Lowland Interactive Systems, Held at Chiang Mai, 1980, Sanga S. and Pisit V. (Eds.), UNU, Japan NRTS-3/UNUP-77, United Nations University Press: Tokyo.

Revenga C., Murray S., Abramovitz J. and Hammond A. (1998) Watersheds of the World: Ecological Value and Vulnerability, World Resources Institute, and Worldwatch Institute: Washington.

Sharp D. and Sharp T. (1981) The desertification of Asia. Asia, 2000 1(4), 40-42.

Sillitoe P. (1993) Losing ground? Soil loss and erosion in the highlands of Papua New Guinea. Land Degradation and Rehabilitation, 5(3), 179-190.

Smadja J. (1992) Studies of climatic and human impacts and their relationship on a mountain slope above Salme in the Himalayan middle mountains, Nepal. Mountain Research and Development, 12(1), 1-28.

\section{REFERENCES}

Alford D. (1992) Streamflow and sediment transport from mountain watersheds of the Chao Phraya basin, northern Thailand: a reconnaissance study. Mountain Research and Development, 12(3), 257-268.

Bass T. (1990) Camping with the Prince, and Other Tales of Science in Africa, Latterworth Press: Cambridge.

Batterbury S. and Warren A. (Eds.) (2001) The African Sahel 25 years after the great drought: assessing progress and moving towards new agendas and approaches. Special Edition of Global Environmental Change, 11(1), 1-8.

Bernard A. (1953) L'evapotranspiration Annuelle de la Foret Equatoriale Congolaise et Sone Influence sur la Pluviosite, IUFRO Congress: Comptes Rendus, Rome, pp. 201-204. 
Bonell M. and Bruijnzeel L.A. (Eds.) (2004) Forests, Water, and People in the Humid Tropics: Past, Present, and Future Hydrological Research for Integrated Land and Water Management, Cambridge University Press: Cambridge.

Bons C. (1990) Accelerated erosion due to clearcutting of plantation forest and subsequent Taungya cultivation in upland West Java. International Association of Hydrological Science, Publication 192, 279-288.

Bosch J. (1979) Treatment effects on annual and dry period streamflow at Cathedral Park. South African Forestry Journal, 108, 29-38.

Brown L. (2001) Eco-Economy: Building an Economy for the Earth, Earthscan and Earth Policy Institute: London and Washington.

Bruijnzeel L. (1990) Hydrology of Moist Tropical Forests and Effects of Conservation: A State of Knowledge Review, UNESCO International Hydrological Programme, Humid Tropics Programme, and the Faculty of Earth Sciences, Free University: Amsterdam, Paris.

Bruijnzeel L.A. (2004) Hydrological functions of tropical forests: not seeing the soil for the trees? Agriculture, Ecosystems and -Environment.

Bruijnzeel L.A., Calder I. and Vertessy R. (2004) Impacts of forest Q13 conversion on streamflow. Forest $\bullet$ Hydrology.

Calder I. (1999) The Blue Revolution: Land Use and Integrated Water Resources, Earthscan: London.

Q14 Calder I. and Aylward B. (•in press) Forest and floods: moving to an evidence based approach to watershed and integrated flood management. Water International.

Chapman G. and Thompson M. (Eds.) (1995) Water and the Quest for Sustainable Development in the Ganges Valley, Cassell:.London.

Chomitz M. and Kumari K. (1998) The domestic benefits of tropical forests: a critical review. The World Bank Research Observer, 13(1), 13-35.

Cutrim E., Martin D. and Rabin R. (1995) Enhancement of cumulus clouds over deforested lands in Amazonia. Bulletin of the American Meteorological Society, 76(10), 1801-1805.

Donovan D. (1981) Fuelwood: how much do we need? Newsletter (DGD 14), Institute of Current World Affairs:.Hanover.

Eckholm E. (1976) Losing Ground: Environmental Stress and Food Problems, Norton: New York.

Edwards K. (1979) The water balance of the Mbeya experimental catchments. East Africa Agriculture and Forestry Journal, 43, 231-247.

Fairhead J. and Leach M. (1998) Reframing Deforestation: Global Analysis and Local Realities: Studies in West Africa, Routledge: London.

Forsyth T. (1996) Science, myth and knowledge: testing Himalayan environmental degradation in Thailand. Geoforum, 27(3), 375-392.

Forsyth T. (2003) Critical Political Ecology: The Politics of Environmental Science, Routledge: London and New York.

Froehlich W. and Starkel L. (1993) The effects of deforestation on slope and channel evolution in the tectonically active Darjeeling Himalaya. Earth Surface Processes and Landforms, 18, 285-290.

Gilmour D., Bonell M. and Cassells D. (1987) The effects of forestation on soil hydraulic properties in the middle Hills of Nepal: a preliminary assessment. Mountain Research and Development, 7, 239-249.

Goudie A. (2000) The Human Impact on the Natural Environment, Fifth Edition, Blackwell: Oxford.

Goudie A. (2004) Dust storms in the global system. Paper Presented at the International Geographical Union Conference, Glasgow.

Gyawali D. (2000) Water in Nepal, Himal Books: Kathmandu.

Hajer M. (1995) The Politics of Environmental Discourse, Clarendon: Oxford.

Hamilton L. (1988) Forestry and watershed management. In Deforestation: Social Dynamics in Watershed and Mountain Ecosystems, Ives J. and Pitt D. (Eds.), Routledge: London, pp. $99-131$.

Hamilton L. and Pearce A. (1988) Soil and water impacts of deforestation. In Deforestation: Social Dynamics in Watershed and Mountain Ecosystems, Ives J. and Pitt D. (Eds.), Routledge: London, pp. 75-98.

- Harper D. and El-Swaify S. (1988) Sustainable agricultural development in north Thailand: conservation as a component of success in assistance projects. In Conservation Farming on Steep Slopes, Moldenhauer W. and Hudson N. (Eds.), Soil and Water Conservation Society of America: Ankeny, pp. 77-92.

Hatch T. (1983) Shifting cultivation in Sarawak. In Proceedings of the Workshop on Hydrological Impacts of Forestry Practices and Reafforestation, Kamis A., Lai F.S., Lee S.S. and Abdul Rahman Mohammed D. (Eds.), Faculty of Forestry, Universiti Pertanian Malaysia: Serdang, pp. 51-60.

Hofer T. (1993) Himalayan deforestation, changing river discharge, and increasing floods: myth or reality? Mountain Research and Development, 13(3), 213-233.

Hofer T. (1998) Floods in Bangladesh. A highland-lowland interaction? Geographica Bernensia, G48, 171.

Hulme M. (2001) Climatic perspectives on sahelian desiccation: 1973-1998. Global Environmental Change, 11(1), 19-29.

ICRAF (International Center for Agroforestry Research) (1999) ICRAF in Southeast Asia, Publicity Brochure, ICRAF:.Bogor.

Ives J. (2004) Himalayan Perceptions: Environmental Change and the Well-Being of Mountain Peoples, Routledge: London.

Ives J. and Messerli B. (1989) The Himalayan Dilemma: Reconciling Conservation and Development, Routledge/UNU: London.

Kienholz H., Schneider G., Bichsel M., Grunder M. and Mool P. (1984) Mapping of mountain hazards and slope stability. Mountain Research and Development, 4(3), 247-266.

Lal R. (1983) Soil erosion in the humid tropics with particular reference to agricultural land development and soil management. International Association of Hydrological Science, 140, 221-239.

Lall J. and Moddie A. (Eds.) (1981) The Himalaya: Aspects of Change, India International Centre: New Delhi; Oxford University Press: Delhi, Bombay, Calcutta, Madras.

Lawton R., Nair U., Pielke R. and Welch R. (2001) Climatic impact of tropical lowland deforestation on nearby montane cloud forests. Science, 294, 584-587.

Leach M. and Mearns R. (Eds.) (1996) The Lie of the Land: Challenging Received Wisdom on the African Environment, James Currey: Oxford. 
Marston R., Kleinman J. and Miller M. (1996) Geomorphic and forest cover controls on monsoon flooding, central Nepal Himalaya. Mountain Research and Development, 16(3), 257-264.

Myers N. (1986) Environmental repercussions of deforestation in the Himalaya. Journal of World Forest Resource Management, 2, 63-72.

Meher-Homji V. (1980) Repercussions of deforestation on Q16 precipitation in Western Karnataka, India. •Aceh Met. Geogph Biokl Series B, 28, 385-400.

Moench M., Caspari E. and Dixit A. (Eds.) (1999) Rethinking the Mosaic: Investigations into Local Water Management, Nepal Water Conservation Foundation:.Kathmandu.

Nicholson S. (1988) Land surface atmosphere interaction: physical processes and surface changes and their impact. Progress in Physical Geography, 12, 36-65.

Nortcliffe S. and Dias A. (1988) The change in soil physical conditions resulting from forest clearance in the humid tropics. Journal of Biogeography, 15, 61-66.

Pereira H. (1989) Policy and Practice in the Management of Tropical Watersheds, Westview Press: Boulder.

Rijsdijk A. and Bruijnzeel L. (1991) Erosion, Sediment Yield and Land-Use Patterns in the Upper Konto Watershed, East Java, Indonesia, Part III: Results of the 1989-1990 Measuring Campaign, Project Communication no 18, Konto River Project, Ministry of Foreign Affairs.

Roe E. (1991) Development narratives, or making the best of blueprint development. World Development, 19(4), 287-300.

Rowntree P. (1988) Review of general circulation models as a basis for predicting the effects of vegetation change on climate. In Forests, Climate and Hydrology: Regional Impacts, Reynolds E. and Thompson F. (Eds.), Kefford Press: pp. 162-193.

Saberwal V. (1997) Science and the desiccationist discourse of the $20^{\text {th }}$ Century. Environment and History, 3, 309-343.

Schwarz M. and Thompson M. (1990) Divided We Stand: Redefining Politics, Technology and Social Choice, Harvester Wheatsheaf: Hertfordshire.

Scott D. and Smith R. (1997) Preliminary empirical models to predict reduction in total and low flows resulting from afforestation. Water SA, 23, 145-140.

Shpak I. (1968) Effect of Forest on Water Balance Components of Drainage Basins, Academy of Sciences of the Ukraine: Kiev, (translated from Russian, 1971, by the Israel Program for Scientific Translations, Jerusalem).
Sivaramakrishnan K. (2000) State sciences and development histories: encoding local forest knowledge in Bengal. Development and Change, 31, 61-89.

Stebbing E. (1937) The threat of the Sahara. Journal of the Royal African Society, 36, 1-35.

Sud Y. and Fennessy M. (1982) A study of the influence of surface albedo on July circulation in semi-arid regions using the GLAS GCM. Journal of Climatology, 2, 105-125.

Tangtham N. and Sutthipibul V. (1989) Effects of diminishing forest area on rainfall amount and distribution in northeastern Thailand. Paper Presented at the FRIM-IHP-UNESCO Regional Seminar on Tropical Forest Hydrology, Kuala Lumpur.

Thapa G. and Weber K. (1995) Status and management of watersheds in the upper Pokhara valley, Nepal. Environmental Management, 19(4), 497-513.

Thomas D. and Middleton N. (1994) Desertification: Exploding the Myth, Wiley: Chichester.

Thompson M., Warburton M. and Hatley T. (1986) Uncertainty on a Himalayan Scale: An Institutional Theory of Environmental Perception and a Strategic Framework for the Sustainable Development of the Himalayas, Ethnographica, Milton Ash Publications: London.

Trimble S. (1983) A sediment budget for coon creek basin in the driftless area, Wisconsin 1853-1977. American Journal of Science, 283, 454-474.

Twidale C. (1982) Granite Landforms, Elsevier: Oxford.

Walker A. (2003) Agricultural transformation and the politics of hydrology in northern Thailand. Development and Change, 24(5), 941-964.

Wilk J., Andersson L. and Plermkamon V. (2001) Hydrological impacts of forest conversion to agriculture in a large river basin in northeast Thailand. Hydrological Process, 15, 2729-2748.

World Water (1981) How trees can combat droughts and floods. World Water, 4, 10.

Xue Y. (1997) Biosphere feedback on regional climate in tropical North Africa. Quarterly Journal of the Royal Meteorological Society, 123, 1483-1515.

Ziegler A. and Giambelluca T. (1997) Hydrological change and accelerated erosion in northern Thailand: simulating the impacts of rural roads and agriculture. Explorations in Southeast Asia Studies: A journal of the Southeast Asian Studies Student Association, 1(1), 1-18. 
hsa194

Keywords: $\quad$ science studies; deforestation; drought; Himalayas; land use; myths; Sahel; water shortages; watersheds 


\section{QUERIES TO BE ANSWERED BY AUTHOR (SEE MARGINAL MARKS Q..)}

IMPORTANT NOTE: You may answer these queries by email. If you prefer, you may print out the PDF, and mark your corrections and answers directly on the proof at the relevant place. Do NOT mark your corrections on this query sheet. Please see the proofing instructions for information about how to return your corrections and query answers.

Q1. As per the style of this encyclopedia, you are requested to provide the department details of your affiliation, if available.

Q2. This reference has not been listed in the reference list. Please provide the reference details.

Q3. This reference has not been listed in the reference list. Please provide the reference details.

Q4. We have changed "Earlier research in the Nepal Himalaya produced" to "Earlier in the Nepal-Himalayan region produced". Please clarify if it retains the intended meaning.

Q5. 'Harper and El Swaify 1983 ' is not mentioned in the Reference list but the same is cited in the text, whereas 'Harper and El Swaify 1988' is mentioned in the Reference list but not cited in the text. Please confirm if the year should be either ' 1983 ' or ' 1988 '.

Q6. This reference has not been listed in the reference list. Please provide the reference details.

Q7. This reference has not been listed in the reference list. Please provide the reference details.

Q8. We have modified this sentence as "Local land-use patterns and vegetation may also have an impact on how far soil erosion..." Please clarify if it retains the intended meaning.

Q9. Please clarify if we may change "of between $44 \mathrm{t} \mathrm{km}^{-2}$ (for the Ping river) in to $256 \mathrm{t} \mathrm{km}^{-2}$ (Nan river)" to "to be between $44 \mathrm{t} \mathrm{km}^{-2}$ (Ping river) and $256 \mathrm{t} \mathrm{km}^{-2}$ (Nan river)".

Q10. This reference has not been listed in the reference list. Please provide the reference details.

Q11. These references have been moved to Further Reading as they have not been cited in text. Please confirm if this is fine.

Q12. Please provide the volume number and page range for this reference.

Q13. Please provide the volume number and page range for this reference.

Q14. Please clarify if this article has since been published. If so, please provide the complete details for this reference.

Q15. 'Harper and El-Swaify 1988 ' has not been cited in text please confirm whether we can move this reference to Further Reading.

Q16. Please provide the spelt-out form of the journal title. 


\section{QUERIES TO BE ANSWERED BY EDITOR (SEE MARGINAL MARKS EQ..)}

IMPORTANT NOTE: You may answer these queries by email. If you prefer, you may print out the PDF, and mark your corrections and answers directly on the proof at the relevant place. Do NOT mark your corrections on this query sheet. Please see the proofing instructions for information about how to return your corrections and query answers.

EQ1. We have noted that there are no cross-references included in the text of your article. Could you confirm that this is correct? If you would like to add some in now, please indicate their position on the proof, and use the look-up list supplied to cite the article Unique IDs. 